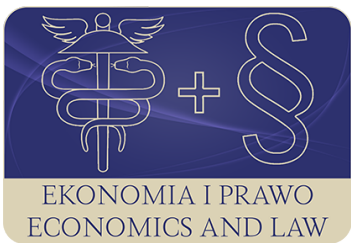

EKONOMIA I PRAWO. ECONOMICS AND LAW

Volume 19, Issue 4, December 2020

p-ISSN 1898-2255, e-ISSN 2392-1625

www.economicsandlaw.pl

EKONOMIA I PRAWO
ECONOMICS AND LAW

ORIGINAL ARTICLE

received 30.03.2019; revised 04.03.2020; accepted 31.12.2020

Citation: Jachowicz, M., Kobylarz, M., \& Podsiadło, P. (2020). The statutory prohibition of advertising of the pharmacy and its activity: legal and economic approach. Ekonomia i Prawo.

Economics and Law, 19(4): 673-697. doi:10.12775/EiP.2020.044.

\title{
The statutory prohibition of advertising of the pharmacy and its activity: legal and economic approach
}

\author{
MICHAE JACHOWICZ \\ corresponding author \\ Jagiellonian University: Medical College in Cracow, Faculty of Pharmacy, Department of Social \\ Pharmacy, ul. Medyczna 9, 30-688 Kraków, Poland \\ $\square$ michal.jachowicz@uj.edu.pl \\ (D) orcid.org/0000-0002-9864-217X \\ MICHAE KOBYLARZ \\ Jagiellonian University: Medical College in Cracow, Faculty of Pharmacy, Department of Social \\ Pharmacy, Poland \\ $\square$ michal.kobylarz@uj.edu.pl \\ (D) orcid.org/0000-0003-1951-1567 \\ PIOTR PODSIADEO \\ Cracow University of Economics, College of Economics, Finance and Law, Department of Public \\ Finance, Poland \\ $\square$ piotr.podsiadlo@uek.krakow.pl \\ (D) orcid.org/0000-0002-4657-3467

\begin{abstract}
Motivation: On a macroeconomic scale, competitiveness is conditioned by both the actions of institutions at the central level, decisions taken by the legislative and executive authorities, as well as the potential of entrepreneurship, which is diversified depending on the level of socio-economic development of society. In turn, the economic, legal and administrative environment created by the state has a significant influence on the possibilities and way of conducting economic activity, because this environment shapes the external factors of the enterprises competitiveness.
\end{abstract}


Aim: The purpose of this article is the legal-economic analysis regarding advertising

of pharmacies and their activities, taking into account a broad spectrum of doctrinal and jurisdiction views. The subject of the analysis is the function and significance of advertising as shaping the potential of enterprise competitiveness in the context of pharmacy activity. The article uses the method of legal regulation analysis.

Results: Taking into account the admissibility of the statutory limitation of the principles of shaping an enterprise competitiveness potential, the necessity should be emphasized of correct interpretation of the law, taking into account the objectives of the introduced restriction and applying only a proportional and adequate mechanism for sanctioning its infringements. In the context of the activities of pharmacies, as public health care facilities, the above remarks have special significance. The undisputed supremacy of the public purpose of a pharmacy activity can not deny the importance of an economic goal as the basic mechanism of an enterprise activity, the achievement of which is an economic guarantee of the public purpose implementation.

Keywords: advertising; competitiveness; enterprises; national economy; pharmacy activity JEL: E62; K20; K32; K33

\section{Introduction}

The level of enterprise competitiveness depends on specific factors which need to be considered in the macro, meso- and microeconomic scale. The macroeconomic factors include the size and structure of production resources, the effectiveness of the use of production resources, the socio-economic system and the economic policy of the state and the possibility of affecting the international environment. Among the mezoeconomic conditions, it is necessary to indicate the equipping with production factors, demand factors, shaping of the appropriate industry layout, as well as the conditions for creating, organizing and managing the enterprises influenced by industry-unique factors, i.e. factors that are only applicable in a specific industry or a few selected industries and shape the nature of competition on the domestic market. The group of microeconomic factors includes the competitive position achieved in the past, the competitive potential of the enterprise and the competitive strategy (Chang \& Cheng, 2018, pp. 458-473).

There is a strong interdependence between factors that affect the increase in the competitiveness of the national economy and the actions of enterprises to improve their own competitiveness. The competitiveness of an enterprise, on the one hand, reflects successful management practices on the part of entrepreneurs, on the other hand, the competitiveness of an enterprise comes from the strength and efficiency of the national economy production structure, its technical infrastructure and other factors determining external effects that may form the basis of the enterprise activity (Chesnais, 1988, pp. 51-119). On a macroeconomic scale, competitiveness is conditioned by both the actions of institutions at the central level, decisions taken by the legislative and executive authorities, as well as the potential of entrepreneurship, which is diversified depending on the level of socio-economic development of society (Zhou et 
al., 2019). In turn, the economic, legal and administrative environment created by the state has a significant influence on the possibilities and way of conducting economic activity, because this environment shapes the external factors of the enterprises competitiveness (Cerne et al., 2015, pp. 429-449).

Conducting pharmacy activity is a special type of economic activity. The social significance and the essence of services provided as part of the pharmacy remains closely related to the profession of a pharmacist as a profession of public trust, and the pharmacy itself constitutes, in accordance with the statutory classification, a public health protection facility. The indicated supremacy of the public purpose over the economic purpose determines the principles of conducting pharmacy activity, including the principles of advertising of pharmacies and their activity (Aikin et al., 2015, pp. 596-618; Casati et al., 2012, pp. 228-245; Cooper, 2013, pp. 254-262; Foley et al., 2018, pp. 327-333).

The purpose of this article is the legal-economic analysis regarding advertising of pharmacies and their activities, taking into account a broad spectrum of doctrinal and jurisdiction views. The subject of the analysis is the function and significance of advertising as shaping the potential of enterprise competitiveness in the context of pharmacy activity, including the interpretation of legal basis taking into consideration the process issues of using sanctioning mechanisms.

\section{Literature review}

\subsection{Concepts of the enterprise competitiveness}

Competitiveness is the result of many factors and many institutions activities, among which the state and its economic policy play an important role (Costantini \& Mazzanti, 2012, pp. 132-153). The possibility of achieving business success by enterprises is determined to a large extent by the economic environment in which they operate (Coccia, 2017, pp. 1048-1061). It is the public authorities that define the economic system, which is the environment more or less favorable to gain a competitive advantage by enterprises. The competitiveness of an enterprise can be defined as the enterprise ability to function in a given industry in the free market economy. At the same time, there is a dependence that the greater the competitiveness, the more reliable the position of the enterprise in the market, and its operation is less exposed to external factors and unfavorable economic conditions. The enterprise competitiveness is its ability: (1) to design, manufacture and sell goods with more attractive prices, quality and other values than the corresponding features of goods offered by competitors, (2) of sustainable development and to achieve, maintain and increase market shares, (3) to raise the efficiency of internal functioning by strengthening and improving its market position, (4) to achieve and maintain a competitive advantage, (5) to constantly provide a suitable set of competing instruments. 
In addition, the enterprise competitiveness is worth considering also in relation to the enterprise ability to increase the value in use perceived by the client (basic competitiveness) and predispositions to gain a lasting competitive advantage in a given market (key competitiveness). Therefore, in a broader perspective, the phenomenon of competitiveness is multilayered and can be described as the ability of enterprises, industry departments, regions and states to obtain a relatively high and stable income and employment level in conditions of international competition.

The ability to produce and sell goods and provide services should always be in relation to effective, beneficial and economic fulfillment of objectives in a competitive market, and the achievement of such ability can be done thanks to a broad understanding of the concept of competitiveness (Aguilera-Caracuel \& Guerrero-Villegas, 2018, pp. 355-372). It is worth taking into consideration the evolution of the trade trend competitiveness theory, which placed its sources in theories of international exchange - from the concept of absolute differences in the production costs of Smith (2008) and the concept of comparative differences of Ricardo (1957, pp. 141-150), Torrens and Mill (1965) to the resources abundance theory of Heckscher and Ohlin (Budnikowski, 2006, pp. 84-90), developed subsequently by Samuelson (Olczyk, 2008b, pp. 23-24). In the 1960s, the achievement of these theories was developed by Vernon (theory of the product cycle) (Hill, 2014, p. 168), Linder (theory of preferences similarity) (Frankel, 1997, pp. 133-134) and Stiglitz and Krugman (theory of economies of scale) (Serwach, 2011, pp. 47-65). It should be noted that the indication of these representatives of economic thought is not accidental, as they all were looking for an answer to the question of what is the source of advantage of one economy over another (Olczyk, 2008a, p. 16). Theories of international trade indicated the complexity of free trade processes and searched for variables explaining the possibility of trade between countries. The concept of competitiveness was decisively influenced by new interpretations and new research directions in this area, that were proposed in the 90s of the twentieth century.

The breakthrough moment of questioning the traditional approach to competitiveness was the debate initiated by Krugman (1994) determining 'anew' the definition of competitiveness. He formulated four theses concerning: (1) the lack of a simple analogy between the enterprise and the economy as a whole (hence, the economy competitiveness can not be treated as the sum of domestic enterprises competitiveness), (2) determining the concept of competitiveness through the increase of national productivity (especially for countries with low involvement in world exchange), (3) distinguishing the trade between countries from the trade between enterprises (in the case of enterprises, the increase in the sales of one enterprise is often associated with a decrease in revenues of another enterprise, i.e. it is a zero-sum game, and countries conduct mutual export and import by exchanging in accordance with the principle of comparative advantages, i.e. it is a non-zero-sum game), and (4) a dangerous impact of the pressure of countries in the field of international competitiveness im- 
provement on the global economy (frequent treatment of mutual trade as a zero-sum game, subsidizing own export and limiting import can lead to trade wars and wasting resources on bad trade policy). Clyde \& Prestowitz (1994), Cohen (1994) and Thurow (1994) responded to the theses formulated in this way. Clyde \& Prestowitz (1994) negated the treatment of every international exchange stream as a non-zero sum game, giving, as an example, contracts for the purchase of new aircraft, produced both by American and European corporations - in the case of an order carried out by the American side, the European side will suffer a loss and vice versa, which means a zero-sum game. Thurow (1994), in turn, challenged the thesis of Krugman that the results in international trade do not affect domestic productivity and thus do not determine the living standard of the population in a given country. He emphasized that a given country must first achieve success in the global economy, and only then could it expect an increase in national productivity and the living standard of its citizens. In turn, Cohen (1994) was of the opinion that productivity should not be focused on as the only appropriate measure of competitiveness, because productivity changes do not answer the question, what contributes to the changes in the competitiveness of the economy and how this competitiveness can be achieved. He postulated the measurement of competitiveness using a number of economic indicators at the same time, which he justified with the fact that analyzed individually do not provide useful information, but together allow to assess the level of competitiveness of a given national economy.

The views presented above indicate a strong emphasis on the dominant role of internal factors in shaping competitiveness and an indication of productivity as the appropriate method of its measurement. A factor approach to the phenomenon of competitiveness was proposed by Porter (1990, p. 72), presenting the model of economy competitiveness based on four factors. The diamond competitiveness model indicated: (1) the quality of production factors ensuring proper supply, which determine the position of the country in terms of production factors and have a direct impact on the country specialization in international markets), (2) the impact of demand factors on the competitiveness of individual industries, determining the nature of domestic demand for a given good or service and the way enterprises adapt to the needs of buyers), (3) the environment (groups), that is existing in the economy informally connected, supporting and at the same time internationally competing branches of industry, (4) strategy, structure and competition of enterprises, degree of strategy implementation and competitive struggle between enterprises, i.e. domestic conditions regarding the creation of enterprises, their organization and management as well as the specificity of national competition. The concept of M. Poter was further developed by Dunning (1993, pp. 7-15), who perfected the diamond model with three new elements, i.e. foreign direct investments, government policy and pro-competitive mentality. Whereas Cho \& Moon (2000) created a nine-factor competitiveness model based on the diamond competition model, which was applied in the competitiveness study of developing or less developed 
countries, forced to build their international competitiveness without having any variables listed by Porter as a base. The adopted solution in this model consisted in a more detailed division of the existing four competitiveness factors, adding new ones and establishing their mutual relations, emphasizing the importance of human factors, i.e. qualified employees, professional managers and engineers, active entrepreneurs and politicians and officials, that mobilize and use physical factors to raise the competitiveness of each country.

Taking into account the above-mentioned discourse on the concept of competitiveness, it should be stated that the competitiveness of the national economy can be considered as built on the competitiveness of enterprises operating within its borders, that operate in a specific legal, financial and environmental environment. Competitiveness of the national economy depends on the competitiveness of enterprises operating in its system (Brammer \& Millington, 2008, pp. 1325-1343). Along with the increase in the quantity and quality of manufactured goods and services provided by enterprises and shaping their prices at a relatively lower level, the level of competitiveness of the national economy increases and its position in the international market becomes better. This means that the increase of competitiveness on the macroeconomic scale is determined by the creation of the basis for the development of micro-competitiveness. Thus, the competitiveness of the economy and the competitiveness of enterprises and sectors creating this economy are interrelated (Porter, 2001, p. 200). Sources of competitiveness originate in an enterprise in the process of its development by shaping unique resources and skills. However, the source of the enterprise competitiveness is also the economic, political and social environment (Fontana et al., 2015, pp. 42-57). The state policy is of particular importance, which directly affects the size and structure of production resources and the efficiency of their use (Halme \& Korpela, 2014, pp. 547-566).

Competitiveness is an enterprise characteristic connected with the environment in which it operates. The structural elements that are subsystems of the "enterprise competitiveness' system are subject to special environmental influences among which various interactions take place. These include the competitiveness potential, competitive advantage, competitive instruments and competitive position. The competitiveness potential is the total of tangible and intangible resources enabling the enterprise to apply optimal instruments of effective competition. In narrow terms, these resources can be classified into three groups. The first group consists of primary resources, among which reference is made to the entrepreneur philosophy and the possibility of gathering in the organization the know-how and the capital necessary to operate. The second group consists of secondary resources, which include material factors of production, human resources, innovations, distribution channels, organization of the enterprise and information resources. The last group consists of resultant resources, which usually mean the image and recognition of the of the enterprise brand, as well as the attachment of the buyer to the product offered. In a wider perspective, the potential of competitiveness includes, apart from broadly understood 
enterprise resources, also its culture, which indicates the ways of economic behavior preferred by owners, managers and employees (e.g. smaller or greater risk tendency, innovative and conservative attitudes), the organizational structure which consists of division of power, division of labor and communication network, strategic vision, defining the subject and mission of the enterprise, and the behavior appropriate for the enterprise, that is the enterprise strategy, the ability to create and implement it (Gonzalez-Ramos et al., 2018, pp. 402-422).

The competitive advantage is the result of using the potential of the enterprise competitiveness to create an attractive market offer. Referring to the competition classification on price competition, which involves the enterprise operation of changes in the level of prices of goods or services and non-price competition, which refers to the use of specific competitive game methods (e.g. quality, warranty conditions, advertising, attractiveness of shopping etc.), enterprises can achieve competitive advantages such as price, quality and information advantage (Flammer, 2015, pp. 1469-1485). In this context, it should be noted that there is the following regularity. Firstly, enterprises competing in a given market strive to achieve and then consolidate their competitive advantage. Secondly, achieving competitive advantage is associated with the enterprise striving to increase competitiveness, which is reflected in the increase in demand - as a result of price competition and demand - through applying various types of non-price competition. In other words, competitive advantage is the configuration of the competitiveness potential elements, which gives the opportunity to generate more effective competing instruments in comparison with other enterprises. The competitive advantage in terms of the competitive position is the result of the use of a set of competition instruments that are components of the competition strategy. The competition instruments include measures taken by the enterprise to acquire purchasers of products offered now and in the future. The set of competition instruments may include such components as: product quality, price, providing potential customers with good access to products through a well-developed distribution and information network, product range, flexibility to adapt products to the needs of customers, more frequent introduction of new products to the market, advertising, sales promotion, terms and warranty period, enterprise image and product brand, payment terms, as well as the diversity of the products offered and the awakening of previously unknown needs (creating needs).

On the other hand, the competitive position should be understood as the result of the competition achieved by the enterprise, that is - as a rule the achievement of a sufficiently high market share, measured by absolute or relative indicators. The competitive position is the result of applying a specific competitive strategy, i.e. a set of competition instruments against a specific competitive potential, which is identified with a set of resources owned by the enterprise (Gallego-Alvarez et al., 2011, pp. 1709-1727). 
The potential of competitiveness, competitive strategy and competitive position are concepts used to describe, analyze and assess competitiveness, which can be understood in at least two ways - as a trait, attribute, result, outcome or as a specific process (Cao \& You, 2017, pp. 51-71). In the case of each of these terms, the occurrence of a positive competitive difference (competitive advantage) or a negative (competitive gap) can be mentioned. When characterizing a specific enterprise from the point of view of its competitiveness, it should be pointed out that the potential of an enterprise competitiveness determines achieving a competitive advantage by this enterprise, which is determined by a specific competitive position. If the assumption is accepted that the enterprise formulates the increase in competitiveness as its strategic goal, it also sets out closely related methods for its implementation, which are intended to help the enterprise to successfully operate in a market economy. Therefore, the competitiveness of an enterprise is identified with achieving success in the market, which can be variously defined (Fuentes-Blasco et al., 2017, pp. 650-666). In basic terms, the concept of competitiveness refers primarily to the enterprise ability to grow, which is usually understood as increasing the market share. The growth can take place by increasing the volume of current production, introducing new products to the market or by improving the products manufactured so far, introducing new technological or organizational solutions. Competitiveness is also a continued ability to cost-effective economic behavior, while efficiency means maintaining and improving the beneficial relation between the use of production factors and the achieved production and financial results (Laforet, 2013, pp. 490-502). Effective behavior is also the ability to sell your products and services on the market and to achieve accordingly high surpluses. Actions taken by an enterprise to improve its competitiveness should be identified with activities that increase the enterprise income, achieving the intended goal as a result of taking risky actions, activity ensuring existence and development, innovative activity leading to gaining an advantage over competitors, obtaining a favorable position in a given market and increase an enterprise recognition in a given market.

However, the significance of the enterprise competitiveness potential may be depreciated due to the supremacy of the social good that determines the essence of its activity. Statutory limitation of shaping the competitiveness potential of an enterprise is a manifestation of the constitutional principle of economic activity freedom and as such should find proportional and adequate justification in the rank of a protected good included in the classification of an important public interest.

\subsection{Legal conditions for advertising of pharmacies}

Advertising of pharmacy and its activities as well as the rules for advertising of medicinal products are subject to the regulation of the Pharmaceutical Law (2001). The legislator clearly differentiates advertising in both of the above-men- 
tioned areas, prohibiting the advertising of pharmacies and their activities, and at the same time allowing advertising of a medicinal product, the conduct of which, however, has been subject to certain restrictions. This distinction was reflected in court jurisdiction, according to which 'regardless of whether we are dealing with advertising of a medicinal product, or advertising of a pharmacy or its activity, it is about increasing the revenue in relation to forecasted revenue that would have been achieved if no advertising action was taken. However, the legislator recognized that in the case of a medicinal product the properly shaped advertising activity may entail certain social benefits, so in principle it allowed the possibility of conducting it. However, the legislator acted conversely in the case of advertising of pharmacy or pharmacy point, or their activity' (Supreme Administrative Court, 2016b). Concentrating the scope of the deliberations within advertising of pharmacies activities, it should be noted that the legislator did not decide on the normative creating of the definition of this type of advertising by correlating it only with the informing function. According to art. 94a $\$ 1$ of the Pharmaceutical Law (2001), 'advertising of pharmacies and pharmacy points and their activities is prohibited'. 'Information about the location and working hours of the pharmacy or pharmacy point do not constitute advertising'. This prohibition falls within the subjective extension under art. 94a $\$$ la of the Pharmaceutical Law (2001), according to which 'advertising of non-pharmacy outlets and their activities relating to medicinal products or medical devices is prohibited'. Prohibition of advertising of a pharmacy, which is a public health protection facility, finds therefore an appropriate reference in the activities of other market enterprises, conducting retail trade in medicinal products issued without a doctor's prescription and therefore qualified as non-pharmacy outlets. The advertising ban is, however, limited in this case to the prohibition of exposure only to that part of the activity and those commercial services which in the context of patient access to the medicinal product and formulating consumer habits are in correlation with the pharmacy activity.

The restriction concerning conducting advertising of pharmacies has been introduced into the Pharmaceutical Law (2001) pursuant to art. 1 point 79 of the Act amending the Pharmaceutical Law and amending certain other acts (2007). Art. 94a of the Pharmaceutical Law (2001) formed under the above act in the original version did not formulate an absolute prohibition on the advertising of the pharmacy and its activity as such, but included in its scope the circulation of certain medicinal products or medical devices. This provision was as follows: 'the advertising is prohibited of activities of pharmacies or pharmacy points addressed to the public, which directly refers to medicinal products or medical devices placed on lists of reimbursed drugs, or medicinal products or medical devices with the same name as medicinal products or medical devices placed on those lists'. The scope of the indicated restriction on advertising was significantly different from the current strict ban on advertising of the pharmacy and its activity. It should also be highlighted that in the original version the provision of art. 94a of the Pharmaceutical Law (2001) did not refer 
to the advertising of non-pharmacy trading facilities and their activities. Disposition of art. 94a of the Pharmaceutical Law (2001), in the version currently in force, was introduced under art. 60 point 7 of the Act on reimbursement of medicines, foodstuffs for particular nutritional uses and medical devices (2011). According to the justification of the above-mentioned draft Act, change of art. 94a of the Pharmaceutical Law (2001) was dictated by the need to strengthen the protection of patients and public finances against the negative effects of pharmacy advertising, determining that 'the objectives of entrepreneurs running pharmacies, including the maximization of profit, must be subject to the requirements resulting from the need to protect the health of patients' (justification of the Government draft on the reimbursement of medicines, foodstuffs for particular nutritional uses and medical devices (2010); Supreme Administrative Court, 2015a). In the literature of the subject, however, it is noted that the amendment of art. 94a of the Pharmaceutical Law (2001) in the direction of a restrictive ban on advertising of pharmacies and their activities, did not find a clear justification, and the objectives for which it was to serve, consisting in elimination of fraud related to the turnover of reimbursable products, could be implemented by other provisions of the Act on reimbursement of medicines, foodstuffs for particular nutritional uses and medical devices (2011). It is also pointed out that at the basis of the ratio legis of the amendment of art. 94a of the Pharmaceutical Law (2001), there was no conviction about the inadmissibility of informing about the pharmacy and its activities in every area of information and that such an interpretation of art. 94a. departs from the adopted legislative assumptions. The prohibition of advertising of pharmacies and their activities was, however, covered ex post by the justification of the Minister of Health and representatives of the pharmacy self-government, according to which this prohibition aims to protect public health, including limiting the tendency among patients to selfheal, abuse drugs, and to buy medicines in amounts that do not meet the actual therapeutic needs. In addition, according to the representatives of the pharmacy self-government, the prohibition of advertising in the previous version gave rise to the development of negative practices and activities significantly deprecating pharmacies and affecting the essence of the profession of pharmacist. Considering that the essence of conducting pharmaceutical activities is the provision of pharmaceutical services, i.e. providing services covered by the pharmacist's profession as a profession of public trust, strengthening the quality of pharmaceutical services at the expense of limiting the tools of market expansion and progression of consumer market conditions should be considered justified. The adopted solution corresponds to the analogue restrictions applicable to other professions of public trust, including the doctor's profession. According to art. $14 \$ 1$ of the Act on medical activities (2011): 'the entity performing medical activities publishes information on the scope and types of health services provided. The content and form of this information can not have the features of advertising'. Correlated with the above solution is the change in the Pharmaceutical Law (2001), which entered into force on June 25, 2017 and under 
which the right to obtain a pharmacy permit was limited only to persons with the right to practice as a pharmacist, being guarantors of the proper standard of provided services, however, this restriction does not apply to entities that, before the amendments to the Act came into force received the above permit, or at least applied for it.

Taking into account the supremacy of the pharmacy public purpose, i.e. protection of public health, and considering the subsidiarity of achieving economic goal by the pharmacy, the legitimacy should be recognized of a normative extension of the ban on pharmacy advertising in the form of binding regulation. The function of a pharmacy as a public health protection unit should be referred to the activity of a pharmacy as an enterprise, and thus the legal admissibility of restriction by the legislator of a constitutional principle of economic activity freedom, expressed in the statutory ban on advertising of conducted activities. The recognition of the above subject in the context of the ban on advertising of pharmacies and their activities is the subject of the court-administrative jurisdiction, according to which "pharmaceuticals are not a classic commercial product. Their production, but also turnover are regulated by law. This circumstance is not therefore without effect on the situation of entities involved in economic activity in this respect. The situation on the pharmaceuticals market depends largely on their attitudes. Interference with this freedom is therefore justified by the legal right protected in this way. Limiting the advertising of pharmacies activities seen in the context of the pharmaceuticals sold is to even potentially protect human health and life from the adverse effects of pharmaceuticals. The principle of freedom of economic activity gives way to an important public interest within the meaning of art. 22 of the Constitution of the Republic of Poland' (Supreme Administrative Court, 2016a). Particularly noteworthy is the position of the Supreme Administrative Court (2016a), according to which, if we look at the protection of human health 'through the prism of damage that can be done to it not only through lack of proper access to pharmaceuticals, but also through 'excessive', or rather too easy access to them, stimulated, among others by all 'promotions', as a result, it should be concluded that in this way specific habits are made in a particular group of consumers, such as pharmacy customers, of purchasing pharmaceuticals, which may lead to the abuse of these substances. A further consequence of such action is the weakening effect of drugs, through their excessive and unjustified with the patient health state consumption'.

\section{Methods}

The subject of this article is to analyse current legal solutions, including in particular determining the regulation of pharmacy activity, taking into account advertising of pharmacies and their activities. The above analysis is carried out in the light of the theory of enterprises competitiveness. The article uses the method of analysis of legal regulation and the descriptive method. 


\section{Substantive scope of pharmacy advertising in terms of Pharmaceutical Law}

Recognizing the desirability of the introduced changes, however, the question should be asked about the direction of interpretation of art. 94a $\$ 1$ of the Pharmaceutical Law (2001) in the current wording, and about determining the subject and the scope of the pharmacy and its activities advertising concept within the meaning of the Pharmaceutical Law (2001).

The Pharmaceutical Law (2001) does not contain a statutory definition of the advertising of pharmacy and its activities concept, formulating pursuant to art. $52 \$ 1$ of the Pharmaceutical Law (2001) the designations of the concept of advertising solely in the context of advertising of medicinal products, according to which 'the advertising of a medicinal product is the activity of informing or encouraging the use of a medicinal product, aimed at increasing: the number of prescriptions, delivery, sale or consumption of medicinal products'. However, taking into account the principle of rationality of the legislator as well as the normative principles of legislative technique, it should be assumed that within a given legal act the lawmaker uses similar terms in the same sense, unless they indicate otherwise. According to art. $147 \$ 1$ and 2 of the Annex to the Regulation of the Prime Minister on the 'Principles of Legal Technique' (2002), 'if in the act or other normative act the meaning of a given term is determined by definition, within this act it is not allowed to use this term in a different sense. If there is a need to deviate from the principle expressed in $\mathbb{1}$, the other meaning of the term is clearly stated and its reference range is determined'. Statutory recognition of advertising of medicinal products should therefore find an appropriate reference to the concept of pharmacy and its activities advertising. The above conviction is confirmed by the court jurisdiction according to which on the basis of the definition contained in art. $52 \$ 1$ of the Pharmaceutical Law (2001), 'it can be stated that the advertisement (as such) is the seller activity consisting in informing or encouraging a specific behavior of the buyer, aimed at increasing their turnover. In the case of advertising of a medicinal product, this 'specific behavior', will be encouraging the use of this product, while in the case of advertising of the pharmacy or its activities, it will be encouraging the use of its services. 'The increase in turnover' of the seller will be in the case of advertising of a medicinal product, the increase in the number of prescriptions, delivery, sale or consumption of medicinal products, and in the case of pharmacy or its activity advertising it will increase the number of transactions carried out or their value' (Supreme Administrative Court, 2016b). In the jurisdiction, indication is at an attempt to circumvent the ban on advertising of pharmacy by using advertising of a medicinal product, noting that "certain forms of promotional activity may constitute both advertising of a medicinal product in accordance with art. $52 \$ 1$ of the Act, as well as advertising of pharmacy activities (...). This type of advertising, meeting the criteria provided for both the advertising of the medicinal product (art. 52 et seq. of the Act) and for the advertising 
of pharmacy activities (art. 94a of the Act) was allowed to 1 January 2012. From that date, it is no longer acceptable in connection with the introduction of an absolute ban on the advertising of pharmacies and pharmacy points or their activities' (Supreme Administrative Court, 2016b). As an example of this kind of dualistic form of advertising it is given "presentation of a list of medicines with a reduced, promotional price, shown by a comparative putting lower price, used by the pharmacy, next to the higher price, defined as 'typical price', 'old price' or in another way, suggesting that the pharmacy periodically sells the medicine at a reduced, promotional price' (Supreme Court, 2007). This kind of message is considered as an encouraging to purchase of a medicine in a pharmacy that uses price promotion, which is a violation of the advertising ban.

Taking into account the consistency of the legal system and the application of systemic interpretation, in order to reconstruct the legal meaning of the concept of pharmacy advertising, reference should be made to the statutory qualification of advertising on the basis of other normative acts. For example, according to art. 4 point 17 of the Act on radio and television (1992), 'advertising is a commercial message originating from a public or private entity in connection with its economic or professional activity, aimed at promoting the sale or at payable use of goods or services; self-promotion is also advertising'. In turn, according to art. 2 point 16a of the Act on spatial planning and development (2003) advertising should be understood as 'popularization in any visual form of information promoting people, enterprises, goods, services, ventures or social movements'. The concept of advertising also occurs on the basis of art. $2^{1} \$ 1$ point 3 of the Act on upbringing in sobriety and counteracting alcoholism (1982), which formulated the meaning category of advertising for alcoholic beverages, while considering the concept of advertising in a broader sense, as particularly important in the context of the above-mentioned provision should be considered the position of the Supreme Administrative Court (2015d), according to which the characteristic element of advertising is 'an element of prompting, persuasion and acquiring this and not another commodity, affecting the emotions of the recipient'. When looking for universal designations of the legal recognition of advertising, reference should also be made to the jurisdiction of the Court of Justice of the European Union (1993), according to which the concept of advertising is covered by 'any activity that participates in the dissemination of messages to inform consumers about the existence or the characteristics of products or services in order to increase sales'.

Qualification of advertising in the context of the statutory ban on advertising of the pharmacy and its activities, has over the years experienced a wide recognition in the jurisdiction of the authorities of the State Pharmaceutical Inspection and administrative courts. According to the position of the Supreme Administrative Court (2016d), 'any activity addressed to the public will be an advertising of the pharmacy activity, regardless of the form and method of its implementation and measures used to implement it, if the purpose of this activity is to increase the sale of medicinal products or medical devices at the pharmacy. There 
is also no doubt that advertising can take various forms of encouragement, for example through leaflets, brochures, posters or newspapers that serve this purpose'. The Supreme Administrative Court (2017) also pointed out that 'advertising of a pharmacy activity is to attract potential customers to purchase goods sold in a pharmacy - regardless of the forms and methods of conducting it and the means used to perform it - if its aim is to increase the sale of medicinal products or medical devices'. The indicated position corresponds with the view of the Supreme Court (2007), according to which 'advertising is all forms of communication, including those that do not contain any elements of evaluation or encouragement to purchase, but can be accepted by their recipients as an incentive to purchase'. Justifying the qualification of the advertising due to the premise of its recipient perception, the Supreme Court referred, inter alia, to art. $16 \$ 1$ point 4 of the Act on combating unfair competition (1993), according to which 'the act of unfair competition in the field of advertising is in particular, a statement that, by encouraging the purchase of goods or services, gives the impression of neutral information'. The basis for shaping the position of the Supreme Court is also art. 2 point a) of the Directive 2006/114/EC of the European Parliament and of the Council of concerning misleading and comparative advertising (2006), according to which 'advertising means representation in any form as part of commercial, economic, craft or liberal profession activities to promote the sale of goods or services, including real estate, rights and obligations'. Considering all the above indications, a violation of the ban on advertising of pharmacy or its activity is any kind of information directed to both potential and existing customers, the main purpose of which is to encourage the use of services offered by the pharmacy to increase pharmacy revenues. It does not matter whether the advertising is addressed to an unlimited group of recipients or only to a closed or marked group. The Supreme Administrative Court (2016c) also emphasized that for the violation of the ban on advertising of a pharmacy or its activity without meaning are the connections and subject qualifications, including connections between the entity advertising and the entrepreneur operating the advertised pharmacy, as well as the fact whether the advertising was run on their own initiative or at the request of another entity. Considering the potential dissimilarity of the entity advertising the pharmacy from the entity operating the pharmacy, it should be emphasized that the entity advertising is subject to penalty for violating the prohibition of advertising of pharmacy or its activities (Supreme Administrative Court, 2015e).

Within the interpretation of the ban on the advertising of the pharmacy and its activities, the concept of advertising should be distinguished from information actions. According to art. 94a. $\$ 1$ of the Pharmaceutical Law (2001) (second sentence), 'information about the location and working hours of the pharmacy or pharmacy point does not constitute advertising'. The indicated distinction of concepts has been clarified in the court jurisdiction, according to which "when distinguishing information from advertising, it must be taken into account that the basic determinant of the advertising message is 
not only a more or less clear incentive to purchase goods, but also the actual intentions of the entity making the message and the reception of the message by entities to which it is addressed. A statement is an advertisement, when the incentive to purchase goods prevails over the information layer - this is the purpose of the sender of the statement and so it is received by the average recipient to whom it was addressed. All promotions, including price, are advertising of the goods and the company that makes them. Whereas, among others price lists that contain only information about the prices of goods or services and are published only to publicize the prices of specific products do not constitute an advertising' (Supreme Court, 2007). The framework of the above considerations include the issue of the distribution of leaflets or newsletters containing information on the prices of products in the pharmacy. In the court jurisdiction the view prevails, according to which placing the logo or name of the pharmacy and the price list in the content of the leaflet with the indication of the validity date of the price is an incentive for the patient to purchase certain medicinal products at a given time, and thus the advertising of the pharmacy (Supreme Administrative Court, 2015a). The inadmissibility is also indicated of the socalled 'associative' advertisement, consisting in including in the leaflet only the logo of the pharmacy without indicating its name. According to the court standpoint, "not placing in distributed newsletters the addresses of pharmacies and their full name could not play a decisive role in the light of the unquestionable factual situation (...). For patients aware of the functioning of pharmacies using the logo (...), leaflets were in fact their advertising, which is not affected by the lack of full pharmacy names or addresses of their locations' (Supreme Administrative Court, 2015f). An inappropriate form of advertising is also an unsuitable display of the pharmacy name, i.e. included in a graphic design, the impact of which may result in an incentive to take advantage of the pharmacy services. The above refers in particular to the names of pharmacies including the formulation that may express an element of incentive (e.g. formulation: cheap medicines, wholesale prices). According to the jurisdiction, "no legal provision prohibits the use in economic activity of a particular design, color or regulates the size of signs and banners, but it should be noted that as part of the ban on pharmacy advertising, there is no permission to such graphic representation of the pharmacy name, that can be accepted by recipients/consumers, as an incentive to make a purchase in a given pharmacy (...). The name of the pharmacy containing the cheap medicines slogan, displayed in a public place, in such a way that the slogan is visible above all, suggests to potential clients of pharmacies with the disputable name the benefits that can be gained by purchasing products in these pharmacies and undoubtedly is characterized with the intention to trigger a specific reaction at potential clients of these pharmacies' (Provincial Administrative Court in Warsaw, 2015). In the context of the deliberations the position of the Supreme Administrative Court (2015b) should also be noted regarding running of the loyalty programs in the pharmacy according to which 'the main goal of the bidding program to reward customers for purchasing prod- 
ucts in specific pharmacies is to encourage to use the services of these pharmacies', which means that running such a program 'is characteristic of advertising activity'.

Bearing this in mind, an advertising of a pharmacy or its activity should be any information the content of which includes any element that evaluates the subject of the service or service provider, while apart from the elements of an external nature and visible to the recipient, the advertiser intention as well as the subjective perception of the communicated content by the addressee are significant. In the literature it is emphasized, however, that the restrictive literal interpretation of art. 94a $\$ 1$ of the Pharmaceutical Law (2001), i.e. recognizing as advertising any information other than information about the location and working hours of a pharmacy or pharmacy point is a matter of unjustified and 'excessive entering of the ban on advertising into economic freedom and commercial information freedom' and as such should be adjusted by applying a historical, system and purposive interpretation (Olszewski, 2016, pp. 967-968). It is also emphasized that the prohibition of advertising of the pharmacy and its activities should be subject to a restrictive interpretation, determined among others by the obligation to implement information requirements resulting from separate legal provisions (Olszewski, 2016, pp. 970-971). An example of this type of regulation is art. $4 \$ 1$ of the Act on information on the prices of goods and services (2014), according to which at 'the place of retail sales and service provision, the price and the unit price of goods (services) are shown in unambiguous, unquestionable and allowing comparison of prices manner', while under the implementing regulation to the above-mentioned Act the requirement to show unit prices is not applicable to medicinal products. However, this requirement applies in the scope of the remaining assortment of the pharmacy. An instruction of art. $4 \$ 1$ of the above-mentioned Act is also interpreted as an obligation to indicate, in the case of a price reduction, the reasons for the reduction. The above understanding of the essence of the ban on advertising of the pharmacy and its activity seems to correlate with the view expressed in the jurisdiction, according to which on the basis of art. 94a $\$ 1$ of the Pharmaceutical Law (2001), after 1 January, 2012, 'every advertising of pharmacies and their activities is forbidden if it is not information about their location and opening hours, if it can not be simultaneously recognized as acceptable under separate regulations' (Supreme Administrative Court, 2015c). It is also important to note the postulate of the distinction between advertising as a message of intentional encouraging character to use services or to purchase goods and the actual implementation of specific activities which, by their very nature, are not statements. Consequently, it is argued that running loyalty programs should not in itself be qualified as an activity of advertising. Advertising should be only an action: (1) in the form of a message and (2) containing a message encouraging to use the offer of the pharmacy (Olszewski, 2016, p. 964). The above concept seems to correspond with the view expressed by the Supreme Administrative Court (2015e), according to which 'it is something else to participate in the financial 
aid program when buying medicines, consisting in the sale of medicines covered by this program, and something else is advertising this activity'.

\section{Legal consequences of the violation of the advertising ban}

Violation of the ban on advertising of pharmacies and their activities is subject to two types of sanctions, the application of which belongs to the competence of provincial pharmaceutical inspector. First of all, according to art. 94a $\mathbb{3} 3$ and 4 of the Pharmaceutical Law (2001), in case of violation of the advertising ban, the provincial pharmaceutical inspector orders, by decision, to stop running such advertising. The decision is immediately enforceable, which means that the ordered obligation to stop advertising is immediately enforceable irrespective of the party's right to appeal the decision to the Main Pharmaceutical Inspector as the second instance body and, consequently, regardless of the inadequate nature of the decision. In accordance with established jurisdiction, if the advertising entity ceases to run it before the date of issuing the decision, the provincial pharmaceutical inspector discontinues the proceedings in accordance with art. $105 \$ 1$ of the Code of Administrative Procedure (1960) due to the pointless proceedings. Failure of the addressee to comply with the ordered obligation to stop advertising is the basis for taking actions aimed at enforcing the imposed duty in the course of administrative execution, including the enforcement of the non-monetary obligation, i.e. imposing a fine in the form of a ruling in order to compel. According to art. 121 $\$ 1-3$ of the Act on enforcement proceedings in administration (1966), the fine in order to compel may be imposed several times in the same or higher amount, however, each fine may not exceed PLN 10,000, and PLN 50,000 for legal persons and organizational units without legal personality. Fines imposed on numerous occasions can not exceed PLN 50,000 in total, and PLN 200,000 in relation to legal persons and organizational units without legal personality. Regardless of the enforcement actions taken, the failure to comply with the obligation to stop advertising may result in the provincial pharmaceutical inspector issuing a decision on the withdrawal of the authorization to operate a pharmacy. According to art. $103 \$ 2$ point 5 of the Pharmaceutical Law (2001) the provincial pharmaceutical inspector may withdraw the authorization if the decision of the provincial pharmaceutical inspector has not been done referred to in art. 94a $\$ 3$ of the Pharmaceutical Law (2001), i.e. the obligation to stop advertising has not been fulfilled. The decision to withdraw the authorization to operate a pharmacy is in this case discretionary, which means that its taking depends on an objective assessment of the circumstances and the choice of one of the alternatives of the proceeding, whereas this decision can not be taken freely, but should be preceded by a comprehensive assessment of the relations pertaining to the essence of the social interest and the legitimate interest of citizens.

The decision of the obligation to stop advertising is not the only sanction for violation of the ban on advertising of the pharmacy and its activities. The 
entity conducting the advertisement is also subject to an administrative penalty imposed in the form of a decision by the provincial pharmaceutical inspector. According to art. 129b $\$ 1$ of the Pharmaceutical Law (2001), 'a fine of up to PLN 50,000 is payable to those who, contrary to the provisions of art. 94a conduct advertising of a pharmacy, pharmacy point, non-pharmacy trading facility and their activities'. According to art. 129b $\$ 2$ of the Pharmaceutical Law (2001), the amount of the penalty shall be determined by taking into account, in particular, the period, degree and circumstances of the violation of the provisions of the Act, as well as any previous violation of the law. The administrative penalty decision is obligatory and is independent on the possible discontinuance of the proceedings in the subject of the decision of the obligation to stop advertising due to the termination of its conduct. An instruction of art. 129b of the Pharmaceutical Law (2001) however, should be compared with the provision of art. 189f $\$ 1$ point 1 of the Code of Administrative Procedure (1960), according to which: 'the public administration body, by the decision, withdraws from the imposition of an administrative penalty and stops at the instruction if the violation is negligible and the party ceases to violate the law'. In accordance with the assumptions of the legislator, expressed in the justification of the draft amendment to the Code of Administrative Procedure (1960), the adoption of art. $189 \mathrm{f}$ was to guarantee 'uniform standards of individuals treatment' and to impose "penalties that are rational and corresponding to the severity of the violation committed' (justification of the Government draft amending the Act: Code of Administrative Procedure and some other acts (2017)). Ratio legis art. 189f of the Code of Administrative Procedure (1960) seems, therefore, to constitute a progressive approach to the perception of the meaning and function of administrative punishment, expressed in court jurisdiction, according to which the purpose of administrative penalty payment is not a retribution for the violation of protected goods, nor is it a reimbursement for the act committed. As a rule, 'a financial penalty - as an administrative sanction - is of preventive importance, its essence is coercion to respect the orders and prohibitions set out in the law' (Constitutional Tribunal, 2015; Provincial Administrative Court in Gorzów Wielkopolski, 2013). It should also be emphasized that the disposition of art. $189 \mathrm{f}$ of the Code of Administrative Procedure (1960), shaping the competence of the body imposing a penalty, was based on the construction of an obligatory binding of the body with its content, which means that in the event of statutory prerequisites, the authority is obliged to waive the imposition of a penalty. According to art. 189f $\$ 1$ point 1 of the Code of Administrative Procedure (1960), the basis for withdrawing from imposing a penalty is the implementation of two conditions: (1) cessation to violate the law and (2) insignificant violation. While the first condition remains subject to the circumstances of an objectively perceived factual situation, the latter is subject to the interpretation of a imprecise idea qualifying the importance of the violation of the law as 'negligible'. The gradation of the violation is gradual. The violation of the law may be: (1) qualified, (2) unqualified, but still significant or constitute (3) insignificant violation. The 
violations of the law with a 'negligible' importance is an insignificant violation, thus not having negative consequences for a legally protected good. Transferring the above considerations to the ground of art. 129b of the Pharmaceutical Law (2001), i.e. issuing by the provincial pharmaceutical inspector a decision on imposing an administrative penalty for violation of the ban on advertising a pharmacy and its activities, it should be noted that the provincial pharmaceutical inspector will be obliged to refrain from imposing a penalty if the advertising entity ceases to run it and if the nature of advertising and the degree of its social impact can be considered negligible. The imposition of a penalty, despite ceasing advertising, would be possible only if it was shown that the degree of social impact of advertising caused a significant violation of the protected good, for what should be considered shaping on the side of patients the proper therapeutic tendencies, in particular rationalization of purchase and acceptance of medicinal products to a degree justified only by health needs. Considering the wide scope of understanding the concept of advertising, as well as the potential complexity and variety of possible advertising messages, it is unreasonable to recognize the categorical and uniform qualification of each advertisement as a significant violation of the protected good. The indicated necessity of differentiating different advertising messages corresponds to the one indicated obligation in art. $129 \mathrm{~b} \$ 2$ of the Pharmaceutical Law (2001) to vary the amount of the penalty due to the degree of law violation. At the same time, it should be stipulated that the failure to state grounds for obligatory withdrawal from the imposition of a penalty under art. 189f $\$ 1$ of the Code of Administrative Procedure (1960) does not mean that there is an absolute obligation to impose it. The Provincial Pharmaceutical Inspector is still entitled to withdraw from the imposition of the penalty in an optional mode, i.e. pursuant to art. 189f $\$ 2$ and 3 of the Code of Administrative Procedure (1960), according to which 'in cases other than those mentioned in $\$ 1$, if it allows to meet the purposes for which an administrative fine would be imposed, the public administration body, by a decision, may set a deadline for the presentation of evidence confirming: (1)elimination of the violation of law or (2) notifying the relevant entities about the violation found, specifying the date and manner of notification. In such cases, the public administration body 'withdraws from the imposition of an administrative cash penalty and limits itself to the instruction if the party presented evidence confirming the enforcement of the order'. Taking into account the content of art. 189f of the Code of Administrative Procedure (1960), the provincial pharmaceutical inspector imposing an administrative penalty is therefore obliged to make a comprehensive justification for the lack of implementation of the grounds, both for obligatory and optional withdrawal from its imposition. The Provincial Pharmaceutical Inspector is in this respect related to the provisions of the Code Administrative Procedure (1960), including the principle of material truth (art. 7), the obligation of exhaustive gathering and examining all evidence (art. 77), the obligation to resolve any doubts as to the content of the legal norm in favor of the party (art. 7a) and the principle of building trust (art. 8). It should therefore be considered that 
the entry into force of art. $189 \mathrm{f}$ of the Code of Administrative Procedure (1960) significantly determined the mechanism of the administrative penalty imposed for infringing the ban on advertising of the pharmacy and its activities, by limiting or at least significantly reducing the availability of the above sanction.

\section{Conclusion}

Each enterprise operates in a specific environment that provides the means necessary to conduct an economic activity and is a recipient of goods and services offered by enterprises. This environment is the source of the factors shaping the competitiveness of an enterprise for which it has no real impact. These are different types of standards, which on the one hand regulate technical and technological processes (technical and ecological standards), and on the other hand regulate market behavior, which is covered by international and national legal regulations (legal norms). This means that external factors of the enterprise competitiveness are determined by the rights resulting from the application of the standards regulating the economic system, according to which enterprises are obliged to conduct their economic activity. In turn, internal competitiveness factors are associated with activities that are the result of making specific decisions in the company.

The impact of legal norms on the competitiveness of an enterprise should be considered both from the perspective of national law that is in force in the given country, and international law, which is applied in connection with conducting economic activity in the international market - e.g. in the single European market.

Taking into account the admissibility of the statutory limitation of the principles of shaping an enterprise competitiveness potential, the necessity should be emphasized of correct interpretation of the law, taking into account the objectives of the introduced restriction and applying only a proportional and adequate mechanism for sanctioning its infringements. In the context of the activities of pharmacies, as public health care facilities, the above remarks have special significance. The undisputed supremacy of the public purpose of a pharmacy activity can not deny the importance of an economic goal as the basic mechanism of an enterprise activity, the achievement of which is an economic guarantee of the public purpose implementation.

\section{References}

Aguilera-Caracuel, J., \& Guerrero-Villegas, J. (2018). How corporate social responsibility helps MNEs to improve their reputation: the moderating effects of geographical diversification and operating in developing regions. Corporate Social Responsibility and Environmental Management, 25(4). doi:10.1002/ csr.1465. 
Aikin, K.J., Betts, K.R., O’Donoghue, A.C., Rupert, D.J., Lee, P.K., Amoozegar, J.B., \& Southwell, B.G. (2015). Correction of overstatement and omission in direct-to-consumer prescription drug advertising. Journal of Communication, 65(4). doi:10.1111/jcom.12167.

Brammer, S., \& Millington, A. (2008). Does it pay to be different: an analysis of the relationship between corporate social and financial performance. Strategic Management Journal, 29(12). doi:10.1002/smj.714.

Budnikowski, A. (2006). Międzynarodowe stosunki gospodarcze. Warszawa: PWE.

Cao, Y., \& You, J. (2017). The contribution of environmental regulation to technological innovation and quality competitiveness. Chinese Management Studies, 11(1). doi:10.1108/CMS-12-2016-0252.

Casati, A., Sedefov, R., \& Pfeiffer-Gerschel, T. (2012). Misuse of medicines in the European Union: a systematic review of the literature. European Addiction Research, 18(5). doi:10.1159/000337028.

Cerne, M., Jaklic, M., \& Skerlavaj, M. (2015). Management innovation enters the game: re-considering the link between technological innovation and financial performance. Innovation, 17(4). doi:10.1080/14479338.2015.11265 30.

Chang, A.Y., \& Cheng, Y.T. (2018). Analysis model of the sustainability development of manufacturing small and medium-sized enterprises in Taiwan. Journal of Cleaner Production, 207. doi:10.1016/j.jclepro.2018.10.025.

Chesnais, F. (1988). Technical cooperation agreements between firms. STI Review, 4 .

Cho, D., \& Moon, H. (2000). National competitiveness: a nine factors approach and its empirical application. Journal of International Business and Economy, $1(1)$.

Clyde, V., \& Prestowitz, J. (1994). Playing to win. Foreign Affairs, 73(4). doi:10.2307/20046815.

Coccia, M. (2017). Sources of technological innovation: radical and incremental innovation problem-driven to support competitive advantage of firms. Technology Analysis \& Strategic Management, 29(9). doi:10.1080/09537325.2016 .1268682 .

Cohen, S. (1994). Speaking freely. Foreign Affairs, 74(3). doi:10.2307/20046818.

Constitutional Tribunal. (2015). Judgement of 21 October 2015 (P 32/12, Dz.U. 2015 poz. 1742).

Cooper, R. (2013). Surveillance and uncertainty: community pharmacy responses to over the counter medicine abuse. Health and Social Care in the Community, 21(3). doi:10.1111/hsc.12012.

Costantini, V., \& Mazzanti, M. (2012). On the green and innovative side of trade competitiveness: the impact of environmental policies and innovation on EU exports. Research Policy, 41(1). doi:10.1016/j.respol.2011.08.004. 
Court of Justice of the European Union. (1993). Judgements of 17 November 1993: Commission v. France (C-68/92, ECR I-5881), Commission v. Luxembourg (C-69/92, ECR 1993, I-5907), Commission v. Spain (C-73/92, ECR 1993, I-5997).

Directive 2006/114/EC of the European Parliament and of the Council of 12 December 2006 concerning misleading and comparative advertising (OJ L 376).

Dunning, J.H. (1993). Internationalizing Porter's diamond. Management International Review, 33.

Flammer, C. (2015). Does product market competition foster corporate social responsibility: evidence from trade liberalization. Strategic Management Journal, 36(10). doi:10.1002/smj.2307.

Foley, M., Kelly, P., Deluca, P., \& Kimergard, A. (2018). Advertising of overthe-counter codeine-containing medicines in the EU: differences in the regulation of advertising between member states. Pharmaceutical Medicine, 32(5). doi:10.1007/s40290-018-0245-7.

Fontana, S., D’Amico, E., Coluccia, D., \& Solimene, S. (2015). Does environmental performance affect companies' environmental disclosure. Measuring Business Excellence, 19(3). doi:10.1108/MBE-04-2015-0019.

Frankel, J. (1997). Regional trading blocks in the world economic system. Washington: Institute for International Economics.

Fuentes-Blasco, M., Moliner-Velazquez, B., Servera-Frances, D., \& Gil-Saura, I. (2017). Role of marketing and technological innovation on store equity, satisfaction and word-of-mouth in retailing. Journal of Product and Brand Management, 26(6). doi:10.1108/JPBM-07-2016-1279.

Gallego-Alvarez, I., Prado-Lorenzo, J.M., \& Garcia-Sanchez, I.M. (2011). Corporate social responsibility and innovation: a resource-based theory. Management Decision, 49(10). doi:10.1108/00251741111183843.

Gonzalez-Ramos, M.I., Donate, M.J., \& Guadamillas, F. (2018). An empirical study on the link between corporate social responsibility and innovation in environmentally sensitive industries. European Journal of International Management, 12(4). doi:10.1504/EJIM.2018.10012420.

Government draft amending the Act: Code of Administrative Procedure and some other acts (print no. 1183) (Poland).

Government draft on the reimbursement of medicines, foodstuffs for particular nutritional uses and medical devices (print no. 3491) (Poland).

Halme, M., \& Korpela, M. (2014). Responsible innovation toward sustainable development in small and medium-sized enterprises: a resource perspective. Business Strategy and the Environment, 23(8). doi:10.1002/bse.1801.

Hill, C. (2014). International business: competing in the global marketplace. New York: McGraw-Hill Education.

Krugman, P. (1994). The competitiveness: a dangerous obsession. Foreign Affairs, 73(2). doi:10.2307/20045917. 
Laforet, S. (2013). Organizational innovation outcomes in SMEs: effects of age, size, and sector. Journal of World Business, 48(4). doi:10.1016/j. jwb.2012.09.005.

Mill, J.S. (1965). Zasady ekonomii politycznej i niektóre jej zastosowania do filozofii spotecznej. Warszawa: PWN.

Olczyk, M. (2008a). Kierunki rozwoju badań nad konkurencyjnością. In N. Daszkiewicz (Ed.), Konkurencyjność: poziom makro, mezo i mikro. Warszawa: PWN.

Olczyk, M. (2008b). Konkurencyjność : teoria i praktyka: na przykładzie polskiego eksportu artykutów przemystowych na unijny rynek w latach 1995-2006. Warszawa: CeDeWu.

Olszewski, W.L. (2016). Komentarz do art. 94a Prawa farmaceutycznego. In W.L. Olszewski (Ed.), Prawo farmaceutyczne: komentarz. Warszawa: Wolters Kluwer.

Porter, M.E. (1990). The competitive advantage of nations. London: Macmillan, New York: Free Press.

Porter, M.E. (2001). Porter o konkurencji. Warszawa: PWE.

Provincial Administrative Court in Gorzów Wielkopolski. (2013). Judgement of 30 January 2013 (II SA/Go 990/12).

Provincial Administrative Court in Warsaw. (2015). Judgement of 06 October 2015 (VI SA/Wa 34/15).

Ricardo, D. (1957). Zasady ekonomii politycznej i opodatkowania. Warszawa: PWN.

Rozporządzenie Prezesa Rady Ministrów z dnia 20 czerwca 2002 r. w sprawie „Zasad techniki prawodawczej” [Regulation of the Prime Minister of 20 June 2002 on the 'Principles of legislative technique'] (Dz.U. 2002 nr 100 poz. 908) (Poland).

Serwach, T. (2011). Od handlu między państwami do handlu na poziomie przedsiębiorstw. Gospodarka Narodowa, 246(3). doi:10.33119/GN/101084.

Smith, A. (2008). Badania nad naturą i przyczynami bogactwa narodów. Warszawa: PWN.

Supreme Administrative Court. (2015a). Judgement of 14 January 2015 (II GSK 385/14).

Supreme Administrative Court. (2015b). Judgement of 20 January 2015 (II GSK $1667 / 13)$.

Supreme Administrative Court. (2015c). Judgement of 20 January 2015 (II GSK $1718 / 13)$.

Supreme Administrative Court. (2015d). Judgement of 31 March 2015 (II FSK $707 / 13)$.

Supreme Administrative Court. (2015e). Judgement of 08 April 2015 (II GSK 1843/14).

Supreme Administrative Court. (2015f). Judgement of 08 April 2015 (II GSK $74 / 14)$. 
Supreme Administrative Court. (2016a). Judgement of 25 August 2016 (II GSK 97/15).

Supreme Administrative Court. (2016b). Judgement of 11 October 2016 (II GSK 1996/15).

Supreme Administrative Court. (2016c). Judgement of 11 October 2016 (II GSK 590/15).

Supreme Administrative Court. (2016d). Judgement of 11 October 2016 (II GSK $682 / 15)$.

Supreme Administrative Court. (2017). Judgement of 24 May 2017 (II GSK 1953/16).

Supreme Court. (2007). Judgement of 02 October 2007 (II CSK 289/07).

Thurow, L. (1994). Microchips, not potato chips. Foreign Affairs, 73(4). doi:10.2307/20046816.

Ustawa z dnia 12 maja 2011 r. o refundacji leków, środków spożywczych specjalnego przeznaczenia żywieniowego oraz wyrobów medycznych [Act of 12 May 2011 on reimbursement of medicines, foodstuffs for particular nutritional uses and medical devices] (Dz.U. 2011 nr 122 poz. 696) (Poland).

Ustawa z dnia 14 czerwca 1960 r. Kodeks postępowania administracyjnego [Act of 14 June 1960 Code of Administrative Procedure] (Dz.U. 1960 nr 30 poz. 168) (Poland).

Ustawa z dnia 15 kwietnia 2011 r. o działalności leczniczej [Act of 15 April 2011 on medical activities] (Dz.U. $2011 \mathrm{nr} 112$ poz. 654) (Poland).

Ustawa z dnia 16 kwietnia 1993 r. o zwalczaniu nieuczciwej konkurencji [Act of 16 April 1993 on combating unfair competition] (Dz.U. $1993 \mathrm{nr} 47$ poz. 211) (Poland).

Ustawa z dnia 17 czerwca 1966 r. o postępowaniu egzekucyjnym w administracji [Act of 17 June 1966 on enforcement proceedings in administration] (Dz.U. 1966 nr 24 poz. 151) (Poland).

Ustawa z dnia 26 października 1982 r. o wychowaniu w trzeźwości i przeciwdziałaniu alkoholizmowi [Act of 26 October 1982 on upbringing in sobriety and counteracting alcoholism] (Dz.U. $1982 \mathrm{nr} 35$ poz. 230) (Poland).

Ustawa z dnia 27 marca 2003 r. o planowaniu i zagospodarowaniu przestrzennym [Act of 27 March 2003 on spatial planning and development] (Dz.U. $2003 \mathrm{nr} 80$ poz. 717) (Poland).

Ustawa z dnia 29 grudnia 1992 r. o radiofonii i telewizji [Act of 29 December 1992 on radio and television] (Dz.U. $1993 \mathrm{nr} 7$ poz. 34) (Poland).

Ustawa z dnia 30 marca 2007 r. o zmianie ustawy Prawo farmaceutyczne oraz o zmianie niektórych innych ustaw [Act of 30 March 2007 amending the Pharmaceutical Law and amending certain other acts] (Dz.U. $2007 \mathrm{nr}$ 75 poz. 492) (Poland).

Ustawa z dnia 6 września $2001 \mathrm{r}$. Prawo farmaceutyczne [Pharmaceutical Law of 6 September 6, 2001] (Dz.U. 2001 nr 126 poz. 1381) (Poland). 
Ustawa z dnia 9 maja 2014 r. o informowaniu o cenach towarów i usług [Act of 9 May 2014 on information on the prices of goods and services] (Dz.U. 2014 poz. 915) (Poland).

Zhou, GC., Zhang, L., \& Zhang, LM. (2019). Corporate social responsibility, the atmospheric environment, and technological innovation investment. Sustainability, 11(2). doi:10.3390/sull020481.

\section{Acknowledgements}

Author contributions: authors have given an approval to the final version of the article. Authors contributed to this work as follows: M.J., M.K. and P.P. developed the concept and designed the study, M.J., M.K. and P.P. collected the data, M.J., M.K. and P.P. analysed and interpreted the data, M.J. and P.P. prepared draft of article, M.J. and P.P. revised the article critically for important intellectual content.

Funding: this research was funded by the Cracow University of Economics, Faculty of Finance and Law statutory sources.

Supplementary information: Sylwia Majda translated this article from Polish into English.

Note: the results of this study were presented at 10th International Conference on Applied Economics Contemporary Issues in Economy (June 27-28, 2019, Torun, Poland). 
